\title{
Study of agricultural economic potential in West Kalimantan using Regional Analysis Techniques
}

\author{
Salma Nurulhuda $^{1}$, Mery Askarina ${ }^{1}$, Si 'ta Romadhoniastri ${ }^{1}$, Afanin Fatkha Azahra ${ }^{1}$, Deatry Kharisma \\ Karim $^{1}$, Muhammad Nadafa Isnain ${ }^{1}$, and Ratih Fitria Putri ${ }^{1 *}$ \\ ${ }^{1}$ Environmental Geography Department, Faculty of Geography, Universitas Gadjah Mada, Yogyakarta, 55281, Indonesia
}

\begin{abstract}
The agricultural resource is one of the most critical sectors in the economy, which contributes a high portion of the growth and development of a particular region. Differences in characteristics and potential between regions give rise to the basic and non-basic sectors, which then affect income contribution. This research aims to analyze the economic potential of the agricultural sector of the regencies and cities in West Kalimantan Province as basic or non-basic sector. Both basic and non-basic sector analysis can be carried out using quantitative-descriptive methods using Shift-Share and Location Quotient (LQ) analysis. The analysis was carried out using secondary data from the Central Statistics Agency (BPS) publication from 2015 to 2020. The results of the LQ analysis show the agricultural sector in Sambas, Bengkayang, Landak, Mempayah, Sanggau, Ketapang, Sintang, Kapuas Hulu, Sekadau, and Kayong Utara are the basic sector. Meanwhile, the agricultural sector in Kubu Raya, Pontianak, and Singkawang are non-basic sector. Agriculture in Melawi Regency has changed from a basic sector in 2015, to a non-basic sector in 2020. The results of the Shift-Share analysis show the agricultural sector in Sambas, Bengkayang, Landak, Mempayah, Sanggau, Ketapang, Kapuas Hulu, Sekadau, Kubu Raya, Pontianak and Singkawang have progressive or advanced growth, while Sintang, Melawi and Kayong Utara have slowed growth.
\end{abstract}

\section{Introduction}

Each region has different characteristics and potential. This difference certainly explains the differences in economic activity and regional income. One of the leading economic sectors in the agricultural sector is its significant contribution to the growth and development of a region. In addition, agriculture is also a sector that always exists because it provides the primary human need, namely food needs. It is shown based on the Central Statistics Agency data, which shows Indonesia's Gross Domestic Product (GDP) in the national agricultural sector at a constant base price in 2020 of $1,378.1$ trillion rupiahs, contributing 12.9 percent of the national GDP 10,722.4 trillion rupiahs. However, this sector is not a definite leading sector in every region.

Leading sectors from various regions need to be studied to determine which economic sectors have the most influence on economic growth that will generate the most income. [1] explained that this leading sector could be identified based on economic theory.
This theory distinguishes the economic sector into two: the leading/basic sector and the non-basic sector. [1] explains that the more basic sectors an area has, the demand for goods and services from that area will also increase so that the flow of the economy is maintained. West Kalimantan is one of the provinces in Indonesia that has suitable land for agricultural cultivation and has rainfall > $2000 \mathrm{~mm} /$ year [2]. Therefore, the agricultural sector has an essential role in the economy in West Kalimantan Province. It can be seen from the most considerable contribution of Gross Regional Domestic Product (GRDP) on Constant Prices and GRDP on Current Prices in West Kalimantan in 2020, which was obtained from the agricultural sector, reached $32,340,499.90$ million rupiahs or covering $24 \%$ of the total GRDP of constant price. Meanwhile, GRDP at prevailing prices in the agricultural sector also produced the most considerable contribution in 2020 , which was $44,765,052.30$ million rupiahs or $20.9 \%$ of the total GRDP at current prices [3].

\footnotetext{
* Corresponding author: ratihfitria.putri@ugm.ac.id
} 
This research aims to analyze the economic potential of the agricultural sector of the regencies and cities in West Kalimantan Province as basic or nonbasic sector. Basic and non- basic sectors can be calculated using several methods, including the Location Quotient (LQ) and Shift-Share methods. The LQ method is carried out by comparing the roles between sectors in regional economic activities [4]. In contrast, the Shift-Share method is used to determine the development of the economic sector and its comparison with other agricultural sectors.

\section{Data and Method}

This research uses the quantitative-descriptive method. The descriptive method helps to describe in an authentic, systematic, and accurate way of the empirical evidence the relationship between the investigated issues. The quantitative method, on the other hand, helps to quantify in a numerical way of data collection, data analysis, and data visualization [5]. This study collects secondary data of the Gross Regional Domestic Product (GRDP) in West Kalimantan from the year 2015 to 2020. The data compares the total and agricultural sector of the GRDP in regencies/cities within West Kalimantan Province to the total and agricultural GRDP in a provincial scale at a constant price. The data is obtained from the Central Statistics Agency (BPS).

\subsection{Location Quotient Analysis}

Location Quotient (LQ) analysis is a tool to determine the leading economic sector in a region. The leading economic sector is synthesized by comparing the proportion of certain economic sector in regencies/cities scale to the proportion of certain economic sector in the provincial scale [6]. Here is the following formula.

$$
L Q=[(Y i k / Y k) /(Y i \mathrm{p} / Y p)]
$$

$\mathrm{LQ}=$ Location Quotient

$\mathrm{Y}_{\mathrm{ik}}=$ GRDP of certain sector in regencies/cities scale

$\mathrm{Y}_{\mathrm{k}}=$ total GRDP in regencies/cities scale

$Y_{\mathrm{ip}}=$ GRDP of certain sector in provincial scale

$\mathrm{Y}_{\mathrm{p}}=$ total GRDP in provincial scale

The LQ value is then determined by this condition: LQ $>1$, means that the sector/sub sector is a leading sector.
$\mathrm{LQ}=1$, means that the sector/sub sector has an equal role with other sectors

LQ $<1$, means that the sector/sub-sector is a nonleading sector.

\subsection{Shift-Share Analysis}

Shift-share analysis is used to examine the economic development in a certain sector of a certain region. This method is able to determine the relative comparison between one economic sector to another [7]. This method comprises of share component (National share or $\mathrm{N}$ ) and shift component (Proportional shift or $\mathrm{P}$ and differential shift or $\mathrm{D}$ ). Here are the formulae of each component.

$$
\begin{aligned}
& N j=Y j 0(Y t / Y 0)-Y j 0 \\
& P j=[(Y i t / Y i 0)-(Y t / Y 0)] . Y i j 0 \\
& D j=[Y i j t-(Y i t / Y i 0)] . Y i j 0
\end{aligned}
$$

$\mathrm{N}_{\mathrm{j}}=$ National share or $\mathrm{N}$

$\mathrm{P}_{\mathrm{j}}=$ Proportional Shift or $\mathrm{P}$

$\mathrm{D}_{\mathrm{j}}=$ Differential Shift or D

$\mathrm{Y}_{\mathrm{j} 0}=$ initial total GRDP in regencies/cities

$\mathrm{Y}_{0}=$ initial total GRDP in province

$\mathrm{Y}_{\mathrm{t}}=$ final GRDP in province

$\mathrm{Y}_{\mathrm{i} 0}=$ initial agriculture based GRDP in province

$Y_{\text {it }}=$ final agriculture based GRDP in province

$\mathrm{Y}_{\mathrm{ij} 0}=$ initial agriculture based GRDP in regencies/cities

$\mathrm{Y}_{\mathrm{ijt}}=$ final agriculture based GRDP in regencies/cities 


\section{Results and Discussion}

\subsection{Location Quotient Analysis}

Table 1. Location Quotient of West Kalimantan Province

\begin{tabular}{lccccccc}
\hline \multicolumn{1}{c}{ Regency/City/Province } & \multicolumn{7}{c}{ Year } \\
\cline { 2 - 7 } Sambas & 2015 & 2016 & 2017 & 2018 & 2019 & 2020 & Avg. \\
\hline Bengkayang & 1.48 & 1.49 & 1.52 & 1.52 & 1.52 & 1.51 & 1.51 \\
Landak & 1.46 & 1.49 & 1.28 & 1.54 & 1.56 & 1.53 & 1.48 \\
Mempayah & 1.58 & 1.59 & 1.62 & 1.62 & 1.62 & 1.59 & 1.60 \\
Sanggau & 1.20 & 1.21 & 1.23 & 1.21 & 1.19 & 1.16 & 1.20 \\
Ketapang & 1.52 & 1.53 & 1.52 & 1.52 & 1.53 & 1.55 & 1.53 \\
Sintang & 1.33 & 1.27 & 1.28 & 1.28 & 1.26 & 1.20 & 1.27 \\
Kapuas Hulu & 1.17 & 1.15 & 1.13 & 1.11 & 1.12 & 1.13 & 1.14 \\
Sekadau & 1.08 & 1.09 & 1.10 & 1.08 & 1.08 & 1.08 & 1.09 \\
Melawi & 1.65 & 1.67 & 1.69 & 1.68 & 1.67 & 1.68 & 1.67 \\
Kayong Utara & 1.01 & 1.01 & 1.02 & 0.99 & 0.98 & 0.98 & 1.00 \\
Kubu Raya & 1.38 & 1.38 & 1.37 & 1.33 & 1.31 & 1.31 & 1.35 \\
Pontianak & 0.67 & 0.66 & 0.67 & 0.66 & 0.66 & 0.67 & 0.67 \\
Singkawang & 0.07 & 0.07 & 0.07 & 0.07 & 0.07 & 0.07 & 0.07 \\
West Kalimantan Province & 0.55 & 0.58 & 0.59 & 0.57 & 0.57 & 0.56 & 0.57 \\
\hline Source: Central Statistics Agg & 1.77 & 1.77 & 1.76 & 1.81 & 1.84 & 1.85 & 1.80 \\
\hline
\end{tabular}

Source: Central Statistics Agency/Badan Pusat Statistik, 2015-2020 (modified)

The Location Quotient Analysis is used to figure out whether the agricultural sector in each regency/city of West Kalimantan Province is considered the basic or non-basic sector. The result of the Location Quotient calculation for the period of 2015-2020 shows that most of the regencies in West Kalimantan Province has a basic sector in agriculture, which is indicated by the LQ value above 1 as seen on Table 1 . There is one regency and two cities that has an LQ value less than 1 . The regency that has an LQ value below 1 is Kubu Raya. The agricultural sector in Kubu Raya only contributes around $16 \%$ of the province GRDP or around 2,844,645.16 million rupiahs in 2020 .

Aside from Kubu Raya regency, the cities in West Kalimantan, Pontianak and Singkawang both also have LQ value less than 1 , which means that agriculture is not a basic sector in the two cities. The proportion of agricultural contribution to the province GRDP for Pontianak and Singkawang cities are $2 \%$ and $13 \%$ respectively, or $405,875.37$ and $890,507.24$ million rupiah according to data retrieved from Central Statistics Agency.

Assessing the trend throughout the years, the LQ tends to fluctuate. The highest value can be found in Sekadau Regency, with the figure of 1.69 in 2017 . The- lowest value of 0.07 belongs to Pontianak City, which shows stagnation throughout 2015-2020. Melawi Regency shows an interesting trend, in which it was a basic sector in the year 2015-2017 with the LQ value of 1.01 and 1.02 but then the figure drops to 0.99 and 0.98 in the year 2018-2020. The average LQ of Melawi Regency for the whole period of 2015-2020 is at 1.00 so it can still be considered a basic sector in agriculture. The map seen on Figure 1 shows that Melawi Regency is the only area that experience a shift from basic sector in 2015 to a non-basic sector in 2020 for the agricultural sector. [8] stated that the agricultural transformation process is tied to labor participation and how it is affected by rural-urban migration. 


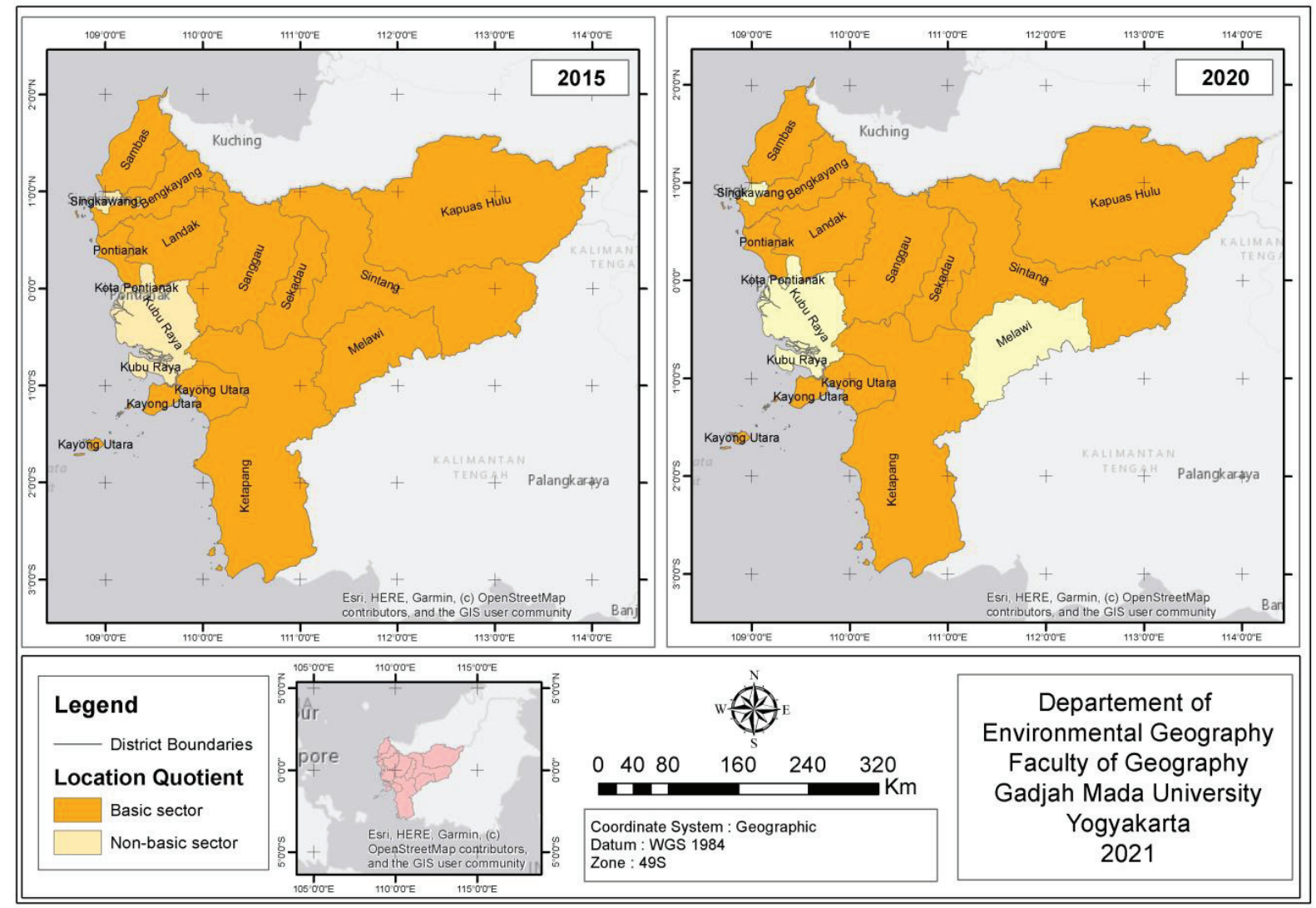

Fig. 1. Location Quotient map of agricultural sector in West Kalimantan 2015-2020

\subsection{Shift-Share Analysis}

Shift-Share Analysis can be used to show the development of economic sectors in West Kalimantan. Moreover, this analysis also show how it is related to other sectors. Shift-Share Analysis of regencies and cities in West Kalimantan is carried out by calculating the components of National Share (N), Proportional Shift (P), and Differential Shift (D) in 2015-2020. The $\mathrm{N}$ value of all regencies and cities in West Kalimantan shows a positive value which indicates a growth in each region. The $\mathrm{P}$ value in all regencies and cities in West Kalimantan Province shows a positive value, which indicates that the agricultural sector in the region has a fast growth rate. Positive D values are found in Bengkayang, Landak, Sanggau, Sekadau, and Kubu Raya Regencies which means those regencies have a competitive advantage in the agricultural sector compared to other regencies. Meanwhile, Sambas, Mempayah, Ketapang, Sintang, Kapuas Hulu, Melawi, Kayong Utara regencies, Pontianak City, and Singkawang City have negative D value which means these regencies and cities have lower competitiveness than other regencies and cities in West Kalimantan. The Shift-Share value (N, D, and P components) for each regency/city is shown on Fig.2.
Based on the results from the shift-share analysis, it shows a positive correlation between the $\mathrm{N}$ value and $\mathrm{P}$ value. The regencies and cities in West Kalimantan Province which have fast agricultural growth have also fast-growing agricultural sector. However, the value of $\mathrm{D}$ can distinguish the rate of growth of each regency and city from the existence of competitiveness in the agricultural sector. Agricultural competitiveness can be affected by the level of production and consumption of agricultural products. In this case, there appears a different demand and supply of agricultural products in each regency and city, thus making the competitiveness of agricultural products different. 
Table 2. Shift-Share Analysis Result of West Kalimantan Province

\begin{tabular}{lccc}
\hline \multirow{2}{*}{ Regency/City/Province } & \multicolumn{3}{c}{ Average } \\
\cline { 2 - 4 } & $(2015-2020)$ & $\mathrm{Pj}$ & $\mathrm{Dj}$ \\
\hline Sambas & $469,727.98$ & $(2015-2020)$ & $-1,583.51$ \\
Bengkayang & $204,204.92$ & $30,514.26$ & $14,692.82$ \\
Landak & $241,304.94$ & $13,454.53$ & $4,581.23$ \\
Mempayah & $176,171.79$ & $16,826.71$ & -167.45 \\
Sanggau & $461,466.28$ & $9,165.91$ & $16,819.31$ \\
Ketapang & $582,761.58$ & $28,877.46$ & $-9,864.44$ \\
Sintang & $328,208.73$ & $33,616.65$ & $-19,895.01$ \\
Kapuas Hulu & $222,459.97$ & $15,051.59$ & $-9,232.35$ \\
Sekadau & $144,823.46$ & $10,052.22$ & $11,523.21$ \\
Melawi & $117,039.72$ & $10,587.30$ & $-6,564.06$ \\
Kayong Utara & $86,810.50$ & $4,747.71$ & $-6,090.47$ \\
Kubu Raya & $614,457.96$ & $4,701.98$ & $7,770.91$ \\
Pontianak & $866,767.43$ & $17,545.85$ & -869.48 \\
Singkawang & $236,136.27$ & $2,398.10$ & $-1,120.72$ \\
West Kalimantan Province & $4,752,341.54$ & $5,729.05$ & 0.00
\end{tabular}

Source: Central Statistics Agency/Badan Pusat Statistik, 2015-2020 (modified)

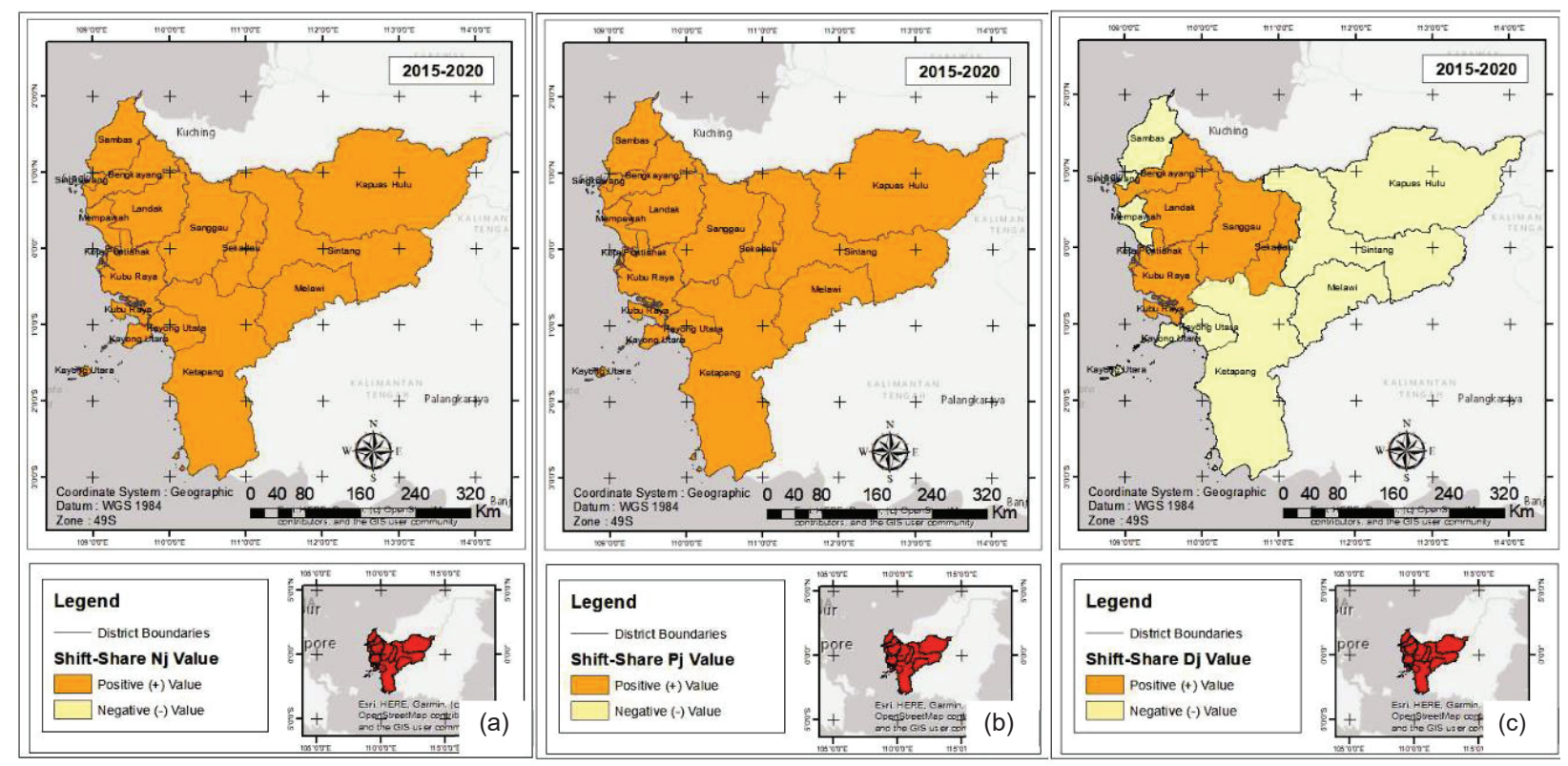

Fig. 2. Shift-Share map of agricultural sector in West Kalimantan 2015-2020 for each components (a) N value (b) P value (c) D value

Agricultural sector competitiveness in West Kalimantan Province is determined by comparing agricultural GRDP in each year. Agricultural GRDP is compared at a constant price according to regencies and cities in West Kalimantan Province. The constant price difference in agricultural GRDP in every year gives impact to the competitiveness of agricultural products. On other word, constant price difference is a tool for measuring whether the competitiveness rises or falls.
The lower of the constant price difference of agricultural products each year, the lower the competitiveness. Agricultural GRDP shows that regencies with the lowest constant prices for agricultural products have a negative $\mathrm{D}$ value. In this case, the growth of the agricultural sector is slow, as happened in the regencies of Sambas, Mempayah, Ketapang, Sintang, Kapuas Hulu, Melawi, Kayong Utara, Pontianak City and Singkawang City. 
The regency with the highest competitiveness is Bengkayang Regency, with a D value of 14,692.82. Meanwhile, the regency with the lowest competitiveness was Sintang Regency, with a value of D -19,895.01. From these differences, it can indicate that the effect of differences in the growth of the agricultural sector is due to the fairly large imbalance of constant prices for agricultural product.

\section{Conclusion}

The result of the Location Quotient calculation shows that most of the regencies in West Kalimantan Province has a basic sector in agriculture, which is indicated by the LQ value above 1 . Aside from the regencies, the cities in West Kalimantan, Pontianak and Singkawang both also have LQ value less than 1, which means that agriculture is not a basic sector in the two cities. The highest value can be found in Sekadau Regency, with the figure of 1.69 in 2017. The lowest value of 0.07 belongs to Pontianak City, which shows stagnation throughout 2015-2020.

Shift-share analysis show how it is related to other sectors. So, the regency has a competitive advantage in the agricultural sector compared to other regencies. From the results of the shift-share analysis, it shows a positive result between the $\mathrm{N}$ value and $\mathrm{P}$ value. This shows that all regencies and cities in West Kalimantan Province have fast agricultural growth in line with the agricultural sector which is also growing fast. To determine the competitiveness of the agricultural sector in the 2015-2020 in West Kalimantan Province, a comparison of agricultural GRDP in that year is needed. The lower the constant price difference of agricultural products each year, the lower the competitiveness.

From the discussion on LQ and Shift-Share analysis, it shows that agricultural growth in the district is faster than in the city. This is evidenced by the fact that Pontianak City and Singkawang City aren't the - basic sectors in agriculture, because they have the lowest LQ value. Likewise, the results of the ShiftShare analysis show a negative competitive level. Meanwhile, the Sanggau and Sekadau districts have fast agricultural growth, because these areas have a basic sector in agriculture with high competitive level according to LQ and Shift-Share analysis.

\section{Acknowledgement}

This Research is part of lecture block of Human and Economic Resource Analysis held by Department of Environmental Geography, Faculty of Geography, Universitas Gadjah Mada. We would like to thank for the guidance to all of lecturer of Human and Economic Resource Analysis.

\section{References}

1. L. Muta'ali, Teknik Analisis Regional Untuk Perencanaan Wilayah Tata Ruang dan Lingkungan, Yogyakarta: BPFG (2015)

2. R. Rizieq, Agrosains 5, 77-91 (2008)

3. BPS Kalimantan Barat, Kalimantan Barat dalam Angka Tahun 2021. Pontianak: Badan Pusat Statistik, 2020.

4. R. S. Septianingrum et. al., IOP Conf. Ser.: Earth Environ. Sci., 451 (2020)

5. S. Siyoto, A. Sodik, Dasar Metodologi Penelitian, Yogyakarta: Literasi Media Publishing (2015)

6. Y. Yurliana, M. R. R., S. Rachmadi, Jurnal Perspektif Pembiayaan dan Pembangunan Daerah 3, 115-128 (2015)

7. E. P. Yuendini, I. N. Rachmi, N. N. A. Puspitasari, R. Harini. M. A. F. Alfana, Jurnal Geografi 16, 128-136 (2019)

8. D. Ge, H. Long, W. Qiao, Z. Wang, D. Sun, R. Yang, Journal of Rural Studies 76, 85-95 (2020) 